\title{
INVOLVEMENT OF HOST MACROPHAGES IN THE IMMUNOADJUVANT ACTIVITY OF AMPHOTERICIN B IN A MOUSE FUNGAL INFECTION MODEL
}

\author{
A. Vecchiarelli, G. Verducci, S. Perito, P. Puccetti ${ }^{\dagger}$, \\ P. MARCONI and F. BISTONI \\ Institute of Medical Microbiology, University of Perugia, \\ Perugia, Italy \\ 'Institute of Pharmacology, University of Perugia, \\ Perugia, Italy
}

(Received for publication November 25, 1985)

\begin{abstract}
We have recently reported the in vivo augmentation of resistance to experimental Candida albicans injection by amphotericin B in mice and have shown that this event is concurrent with the appearance in the spleen of a highly candidacidal cell population reactive in vitro against ${ }^{51} \mathrm{Cr}$-labeled yeast cells. In the present study we characterize these in vitro fungicidal effectors as macrophages and describe the conditions of amphotericin B treatment most suitable for inducing candidacidal activity. We also report that macrophages from intact mice can be activated in vitro to become cytotoxic against Candida. The possible mechanisms through which the amphotericin B activated macrophages exert their increased anti-Candida activity are also investigated.
\end{abstract}

We have previously shown that amphotericin B $(\mathrm{AmB})$ can, under selected experimental conditions, protect mice against systemic challenge with Candida albicans by means of a mechanism largely independent of its chemotherapeutic antifungal activity1). Because of the well known "adjuvant-like" properties of $\mathrm{AmB}^{2,3)}$, we started to examine its effects on isolated components of the host defense system, particularly those with candidacidal activity ${ }^{4,5)}$. In the present paper, we report on the activation of splenic macrophages by in vivo or in vitro exposure to $\mathrm{AmB}$, and define the experimental conditions suitable for achieving optimal anti-Candida immunoadjuvant effects. Studies are also described aimed at clarifying the cellular mechanisms through which AmB confers strong anti-Candida activity on macrophages. This effect apparently involves a more rapid ingestion of the yeast combined with greater phagocytic ability of individual macrophages; on incubation of these effectors with live Candida, marked inhibition of hyphae formation is observed.

\section{Materials and Methods}

Mice

Hybrid (BALB/c $\mathrm{Cr} \times \mathrm{DBA} / 2) \mathrm{F} 1\left(\mathrm{CD} 2 \mathrm{~F} 1: \mathrm{H}-2^{\mathrm{d}} / \mathrm{H}-2^{\mathrm{d}}\right)$ mice were obtained from Charles River Breeding Laboratories, Calco, Milan, Italy.

Chemicals

AmB (Fungizone) kindly supplied by E. R. Squibb \& Sons, Inc., Princeton, N. J., was provided in vials containing $50 \mathrm{mg}$ of $\mathrm{AmB}$ and $41 \mathrm{mg}$ of sodium deoxycholate with $25.2 \mathrm{mg}$ of sodium phosphate as a buffer. The drug was dissolved in sterile, non-pyrogenic $5 \%$ glucose in $\mathrm{H}_{2} \mathrm{O}$ and injected into the mice intraperitoneally (ip) in a volume of $0.1 \mathrm{ml} / 10 \mathrm{~g}$ of body weight. Under these conditions a solution of $1 \mathrm{mg}$ of $\mathrm{AmB}$ per $\mathrm{ml}$ gave the routinely used dose of $10 \mathrm{mg}$ of $\mathrm{AmB}$ per $\mathrm{kg}$. 


\section{C. albicans}

The $C$. albicans strain (laboratory identification name, CA-6) used throughout this study was isolated from a clinical specimen and identified by MARCONI et al ${ }^{6)}$ according to the taxonomic criteria of VAN UDEN and BUCKELY ${ }^{7)}$. The yeast was grown at $28^{\circ} \mathrm{C}$ under slight agitation in low-glucose Winge medium composed of glucose $0.2 \%(\mathrm{w} / \mathrm{v})$ and yeast extract (BBL, Microbiology Systems, Cockeysville, Md.) $0.3 \%(w / v)$ until a stationary phase of growth was reached (about 24 hours). Under these conditions, the culture gave a yield of approximately $2.8 \times 10^{8}$ cells per $\mathrm{ml}$, and the organism grew as an essentially pure yeast-phase population. After the 24-hour culture, cells were harvested by low-speed centrifugation $(1,000 \times g)$, washed twice in saline, and diluted to the desired density. In the in vivo studies, C. albicans was injected intravenously via the tail vein in a volume of $0.5 \mathrm{ml}$ per mouse.

\section{Cell Fractionation Procedures}

(i) Plastic Adherence: Forty million effector cells suspended in a volume of $10 \mathrm{ml}$ of complete RPMI 1640 were incubated for 3 hours at $37^{\circ} \mathrm{C}$ in a $5 \% \mathrm{CO}_{2}$ atmosphere in $93-\mathrm{mm}$ petri dishes (Nunc, Roskilde, Denmark). At the end of the incubation, the dishes were extensively washed with RPMI 1640 medium to remove the nonadherent cells. The adherent cells were recovered by scraping with a rubber policeman, washed, and resuspended (viability, 80 to $90 \%$ ) in complete RPMI 1640.

(ii) Nylon Column: Effector cells were passed over a nylon fiber column as previously described ${ }^{8)}$. Briefly, the sterile nylon columns were rinsed with $20 \mathrm{ml}$ of RPMI supplemented with $5 \%$ fetal calf serum. The columns were drained of excess medium and then replaced in sterile syringe covers and put in a $\mathrm{CO}_{2}$ incubator at $37^{\circ} \mathrm{C}$ at least 1 hour before loading of cells. Then $10^{8}$ cells in a volume of $2 \mathrm{ml}$ were added to the column and washed into the nylon wool with 0.5 to $1 \mathrm{ml}$ of warm $\left(37^{\circ} \mathrm{C}\right)$ medium. The columns were replaced in the sterile syringe covers and left for 45 minutes at $37^{\circ} \mathrm{C}$. The columns were then washed slowly with warm $\left(37^{\circ} \mathrm{C}\right)$ medium, the first $25 \mathrm{ml}$ of effluent was collected in $50-\mathrm{ml}$ conical tubes, and the cells were pelletted at $290 \times g$ for 10 minutes at $4^{\circ} \mathrm{C}$. Cell recovery was about $30 \%$.

(iii) Carbonyl-iron Powder and Magnet: Removal of phagocytic cells from the effector cell population was performed as previously described ${ }^{9)}$. Briefly, $25 \mathrm{ml}$ of spleen cell suspension $\left(10^{7}\right.$ cells per $\mathrm{ml}$ ) was incubated with $25 \mathrm{mg}$ of carbonyl-iron powder (G.A.F. Corp., New York, N.Y.) in a 50-ml conical tube (Falcon Plastics, Oxnard, CA) for 60 minutes at $37^{\circ} \mathrm{C}$. To remove the cells that ingested iron particles, the tube was placed on the top of a magnet, and the supernatant was removed. This last step was repeated six to eight times. The cells were then washed and used as effectors in the microcytotoxicity assays.

(iv) Treatment with Anti-theta(Anti-Thy 1.2) Serum Plus Complement: Monoclonal antibodies to Thy 1.2 were purchased from New England Nuclear Corp., Boston, MA (lot LK 114). Thirty million spleen cells were preincubated with anti-Thy 1.2 antiserum diluted $1: 100$ in complete RPMI 1640 medium for 30 minutes at room temperature, washed once in complete RPMI 1640, suspended in a $1: 4$ dilution of low-toxicity-m rabbit complement (Cedarlane Laboratories, Hornby, Ontario, Canada), and incubated for 45 minutes at $37^{\circ} \mathrm{C}$. The surviving cells were then washed twice and counted. In all experiments a complement control was performed in which the first incubation was in medium alone and the second incubation was with complement. Cell recovery was between 50 and $60 \%$.

(v) Treatment with Anti-Asialo GM1 Antiserum Plus Complement: The antiserum, previously shown to react selectively with mouse NK cells ${ }^{10)}$ was obtained from Wako Chemicals GmbH, Düsseldorf, West Germany. Spleen cells were treated with a 1/200 dilution of antiserum in RPMI 1640 medium for 30 minutes at room temperature, washed twice, suspended in a $1 / 4$ dilution of low-toxicity-m rabbit complement, and incubated for 1 hour at $37^{\circ} \mathrm{C}$. The surviving cells were then washed twice, counted, and tested for residual activity in the microcytotoxicity assays.

Preparation of Effector Cells

For the in vitro assays, effector cells from 5 to 10 animals were pooled. Spleen cell suspensions were obtained by standard methods. 
${ }^{51} \mathrm{Cr}$-release Assay against C. albicans

The candidacidal activity of various effector cell populations was assessed by means of a previously described method ${ }^{11)}$. Briefly, $2 \times 10^{8}$ C. albicans cells were incubated for 2 hours at $37^{\circ} \mathrm{C}$ under $5 \%$ $\mathrm{CO}_{2}$ with $300 \mu \mathrm{Ci}$ of $\mathrm{Na}_{2}{ }^{-51} \mathrm{CrO}_{4}$ (Amersham International Ltd., Amersham, England), washed three times in saline, counted, and resuspended in medium to a density of $5 \times 10^{5} \mathrm{cells} / \mathrm{ml}$. Under standard labeling conditions, $5 \times 10^{4}$ C. albicans cells gave $2,000 \pm 500 \mathrm{cpm}$. Various numbers of effector cells in $0.1 \mathrm{ml}$ were mixed in U-shaped 96-well microtiter plates with $5 \times 10^{4}$ radiolabeled C. albicans cells in $0.1 \mathrm{ml}$. After 4 hours of incubation at $37^{\circ} \mathrm{C}$ under $5 \% \mathrm{CO}_{2}$, the plates were centrifuged at $800 \times g$ for 10 minutes. The radioactivity in $0.1 \mathrm{ml}$ of the supernatant was measured on a $\gamma$-scintillation counter. The base-line ${ }^{51} \mathrm{Cr}$-release was that of $C$. albicans incubated alone in complete RPMI 1640 medium, and in no case did it exceed $20 \%$ of total counts per minute incorporated by target cells.

Experimental results have been expressed as the percent lysis in the experimental group (quadruplicate samples) above the base-line control by the following formula; specific ${ }^{51} \mathrm{Cr}$-release $(\%)=\mathrm{cpm}$ (experimental group) $-\mathrm{cpm}$ (spontaneous release) $/(0.5 \times$ total $\mathrm{cpm}) \times 100$, where total $\mathrm{cpm}$ is the radioactivity incorporated by $5 \times 10^{4}$ C. albicans cells.

\section{Plate Counts}

Phagocytic cells $\left(5 \times 10^{5}\right.$ in $0.1 \mathrm{ml}$ per well $)$ were infected with unlabeled $C$. albicans cells $\left(5 \times 10^{4}\right.$ cells in $0.01 \mathrm{ml}$ per well). After 1 or 4 hours of incubation at $37^{\circ} \mathrm{C}$ under $5 \% \mathrm{CO}_{2}$, the plates were vigorously shaken, and serial dilutions were made in distilled water from each well. Plates (duplicate samples) were made by spreading each sample on Sabouraud glucose agar. The number of cfu was determined after 18 hours of incubation at $37^{\circ} \mathrm{C}$. Control cultures consisted of C. albicans cells incubated without effector cells.

\section{Phagocytic Activity}

The ability of adherent spleen cells to phagocytize heat inactivated $C$. albicans cells was measured by incubating $5 \times 10^{8}$ cells per $\mathrm{ml}$ in U-shaped 96-well microtiter plates with $25 \times 10^{8}$ C. albicans cells per $\mathrm{ml}$ for various times.

After the adherent $0.1 \mathrm{ml}$ of spleen cells were incubated with $0.1 \mathrm{ml}$ of yeast cells, the wells were washed. After that the cells were removed and stained with May-Grunwald Giemsa. The number of intracellular $C$. albicans cells was then determined microscopically by counting the yeast cell content of 100 cells. The counts were done in duplicate by two different observers and the results were averaged.

\section{Statistical Analysis}

Differences in survival times were analyzed by the Mann-Whitney U-test. Differences in the number of cfu or specific radiolabel release in the in vitro microcytotoxicity assay were determined by the Student's " $t$ " test.

\section{Results \\ Effect of AmB Administration on In Vivo Resistance against \\ C. albicans Infection and In Vitro Cytotoxic Activity of Spleen Cells}

To confirm our previous observations on the AmB-induced increase in resistance to C. albicans infection and augmentation of cell-mediated immunity by splenic effectors in vitro ${ }^{1)}, \mathrm{CD} 2 \mathrm{~F} 1$ mice were given a single ip injection of $\mathrm{AmB} 10 \mathrm{mg} / \mathrm{kg}$ at various times before the intravenous challenge with $10^{8}$ C. albicans cells. Groups of mice receiving the drug according to the same schedule were used as donors of spleen cells to be reacted in vitro against radiolabeled C. albicans particles. Table 1 shows the results. It is apparent that AmB treatment considerably enhanced the in vivo resistance of mice to microbial challenge even when the latter was performed $6 \sim 8$ days after exposure to the drug, at a time when no direct ("chemotherapeutic") effect of AmB could be expected to occur ${ }^{1)}$. Table 1 also shows that 
Table 1. Effect of in vivo administration of $\mathrm{AmB}$ on both resistance to $C$. albicans infection and in vitro candidacidal activity of spleen cells.

\begin{tabular}{|c|c|c|c|c|c|}
\hline \multirow{2}{*}{$\begin{array}{c}\text { Time of in vivo } \\
\text { treatment } \\
\text { with } \mathrm{AmB}^{\mathrm{a}}\end{array}$} & \multicolumn{2}{|c|}{ Mortality $^{\mathrm{b}}$} & \multirow{2}{*}{$\begin{array}{l}\text { Spleen } \\
\text { cellularity } \\
\left(\times 10^{\circ}\right)\end{array}$} & \multicolumn{2}{|c|}{${ }^{51} \mathrm{Cr}$ Specific release $(\%)^{\mathrm{f}}$} \\
\hline & $\mathrm{MST}^{\mathrm{c}}$ & $\mathrm{D} / \mathrm{T}^{\mathrm{d}}$ & & 100: 1 & $25: 1$ \\
\hline None & 4.5 & $10 / 10$ & 80.3 & 10.9 & 2.0 \\
\hline 1 & $>60$ & $1 / 10^{*}$ & 78.5 & $16.3^{*}$ & $4.9 *$ \\
\hline 2 & $>60$ & $2 / 10 *$ & 76.6 & $18.0^{*}$ & $5.3^{*}$ \\
\hline 4 & $>60$ & $2 / 10 *$ & 84.5 & $21.1 *$ & $5.5^{*}$ \\
\hline 6 & $>60$ & $3 / 10^{*}$ & 73.7 & $36.4 *$ & $10.6^{*}$ \\
\hline 8 & $>60$ & $3 / 10^{*}$ & 84.1 & $26.1^{*}$ & $7.0 *$ \\
\hline 12 & 5.0 & $10 / 10$ & 80.2 & 11.7 & 3.2 \\
\hline
\end{tabular}

a $\mathrm{AmB}(10 \mathrm{mg} / \mathrm{kg})$ was given as a single ip injection a number of days before microbial challenge or collection of splenocytes for the in vitro assay (day 0 ).

b 8-Week old CD2F1 mice were challenged by iv route with $1 \times 10^{6} \mathrm{C}$. albicans cells.

c MST: Median survival time (days).

d D/T: Dead mice at day 60 over total animals tested.

e The values reported are the means of individual counts of ten spleens for each experimental group. Standard errors, usually $<6 \%$, have been omitted.

1 Ratios are effector to target cells. Data are the means of quadruplicate samples. Standard errors, usually $<1.5 \%$, have been omitted.

* $\quad P<0.01$ according to Mann-Whitney U-test in vivo Student's " $\mathrm{t}$ " test in vitro (AmB-treated versus untreated).

Table 2. Effect of separation by adherence on plastic surfaces, nylon wool passage or carbonyl-iron and magnet treatment on candidacidal activity of splenocytes from normal or AmB-treated CD2F1 mice.

\begin{tabular}{lcccc}
\hline \multirow{2}{*}{ Effector cell population } & Treatment & \multicolumn{2}{c}{${ }^{51}$ Cr Specific release (\%) } \\
\cline { 3 - 5 } with AmB $^{\mathrm{N}}$ & & $10: 1^{\mathrm{b}}$ & $5: 1$ & $2.5: 1$ \\
\hline Untreated cells & - & 10.7 & 5.4 & 2.0 \\
Plastic nonadherent cells & - & 9.0 & 8.0 & 7.4 \\
Plastic adherent cells & - & $18.6^{*}$ & $9.5^{*}$ & $3.8^{*}$ \\
Nylon wool-nonadherent cells & - & $0.9^{*}$ & $0.4^{*}$ & 0.2 \\
Carbonyl-iron+magnet-treated cells & - & $2.4^{*}$ & $1.3^{*}$ & 0.3 \\
Untreated cells & + & 20.6 & 15.4 & 8.6 \\
Plastic nonadherent cells & + & $5.7^{*}$ & $4.8^{*}$ & $2.3^{*}$ \\
Plastic adherent cells & + & $36.2^{*}$ & $23.8^{*}$ & $10.3^{*}$ \\
Nylon wool-nonadherent cells & + & $0.6^{*}$ & $0.3^{*}$ & $0.4^{*}$ \\
Carbonyl-iron +magnet-treated cells & + & $1.7^{*}$ & $0.5^{*}$ & $0.2^{*}$ \\
\hline
\end{tabular}

a $\mathrm{AmB}(10 \mathrm{mg} / \mathrm{kg})$ was given ip as a single injection 8 days before in vitro assay.

b Ratios are effector to target cells. Data are the means of quadruplicate samples. Standard errors, usually $<1.5 \%$, have been omitted.

* $\quad P<0.01$ (fractionated versus unfractionated) according to the Student's " $\mathrm{t}$ " test.

changes in the candidacidal potential of spleen cells in vitro followed a pattern most similar to that observed in vivo, with peak levels of reactivity at about 6 days after treatment. One thing to be noted in this experiment is that at no time after AmB exposure did spleen cellularity change, thus suggesting that activation was the major cellular mechanism involved in the in vivo effect.

\section{Characterization of Effector Cells, Removal of}

Adherent and Phagocytic Cells

To characterize the effector cell responsible for cytotoxic activity against $C$. albicans in our system, we studied the effects of removal of plastic or nylon adherent cells from the splenic population of AmB- 
Table 3. Effect of treatment with different antisera plus rabbit complement on the candidacidal activity of splenocytes from normal or AmB-treated CD2F1 mice.

\begin{tabular}{lcccc}
\hline \multirow{2}{*}{ Effector cell population } & \multirow{2}{*}{$\begin{array}{c}\text { Treatment } \\
\text { with AmB }^{\mathrm{a}}\end{array}$} & \multicolumn{3}{c}{${ }^{{ }^{51} \mathrm{Cr} \text { Specific release }(\%)^{\mathrm{b}}}$} \\
\cline { 3 - 5 } & - & $10: 1$ & $5: 1$ & $2.5: 1$ \\
\hline Untreated cells & - & 15.6 & 9.5 & 4.7 \\
Complement treated cells & - & 14.1 & 9.6 & 5.1 \\
Anti-Thy 1.2+complement treated cells & - & 15.2 & 9.8 & 5.4 \\
Anti-Asialo GM1 + complement treated cells & + & 28.6 & 10.3 & 5.3 \\
Untreated cells & + & 26.7 & 17.8 & 11.6 \\
Complement treated cells & + & 26.4 & 18.6 & 10.2 \\
Anti-Thy 1.2+complement treated cells & + & 26.1 & 16.6 & 8.3 \\
Anti-Asialo GM1 + complement treated cells & + &
\end{tabular}

a $\mathrm{AmB}(10 \mathrm{mg} / \mathrm{kg})$ was given ip as a single injection 8 days before in vitro assay.

b Ratios are effector to target cells. Data are the means of quadruplicate samples. Standard errors, usually $<1.5 \%$, have been omitted.

Table 4. Effect of treatment schedule with $\mathrm{AmB}$ both on resistance to systemic infection with C. albicans and candidacidal activity of spleen cells from $\mathrm{CD} 2 \mathrm{~F} 1$ mice.

\begin{tabular}{|c|c|c|c|c|c|c|}
\hline \multirow{2}{*}{$\begin{array}{l}\text { Treatment } \\
\text { schedule } \\
\text { (days) }^{\mathrm{a}}\end{array}$} & \multirow{2}{*}{$\begin{array}{l}\text { Cumulative } \\
\text { dose of AmB } \\
(\mathrm{mg} / \mathrm{kg})\end{array}$} & \multicolumn{2}{|c|}{ Mortality ${ }^{\mathrm{b}}$} & \multicolumn{3}{|c|}{${ }^{51} \mathrm{Cr}$ Specific release $(\%)$} \\
\hline & & $\mathrm{MST}^{\mathrm{c}}$ & $\mathrm{D} / \mathrm{T}^{\mathrm{d}}$ & $10: 1^{e}$ & $5: 1$ & $2.5: 1$ \\
\hline None & - & 5.5 & $10 / 10$ & 8.0 & 6.2 & 5.2 \\
\hline 8 & 10 & $>60$ & $3 / 10^{*}$ & $22.1^{*}$ & $18.9 *$ & $10.8^{*}$ \\
\hline 8 & 50 & $>60$ & $1 / 10^{*}$ & $24.5^{*}$ & $19.9 *$ & $12.6^{*}$ \\
\hline $12,11,10,9,8$ & 10 & $>60$ & $4 / 10^{*}$ & $24.3^{*}$ & $18.3^{*}$ & $15.7 *$ \\
\hline $12,11,10,9,8$ & 50 & $>60$ & $0 / 10^{*}$ & $23.1^{*}$ & $17.4^{*}$ & $10.3^{*}$ \\
\hline $16,14,12,10,8$ & 10 & 5.5 & $8 / 10$ & 8.2 & 5.1 & 2.5 \\
\hline $16,14,12,10,8$ & 50 & 4 & $7 / 7$ & 9.3 & 6.4 & 3.9 \\
\hline
\end{tabular}

a AmB was given ip before microbial challenge or collection of splenocytes for the in vitro assay (day 0 ).

b 8-Week old CD2F1 mice were challenged by iv route with $1 \times 10^{8} \mathrm{C}$. albicans cells.

c MST: Median survival time (days).

d D/T: Dead mice at day 60 over total animals tested.

e Ratios are effector to target cells. Data are the means of quadruplicate samples. Standard errors, usually $<1.5 \%$, have been omitted.

* $\quad P<0.01$ according to Mann-Whitney U-test in vivo and Student's " $\mathrm{t}$ " test in vitro (AmB-treated versus untreated).

treated animals. Concurrently, the impact of treatment with carbonyl-iron +magnet, which removes phagocytic cells, was also studied. Table 2 shows the results. It is apparent that the cells with candidacidal properties activated by $\mathrm{AmB}$ showed an adherence and phagocytic pattern typical of macrophages.

\section{Treatment with Antisera Plus Complement}

Various antisera directed against specific cell membrane antigens were used to further characterize the cells responsible for anti-Candida cytotoxic activity in our system after exposure to AmB. Table 3 shows that treatment with anti-Thy 1.2 plus complement or anti-Asialo GM1 plus complement, which affect mature $T$ cells and natural killer lymphocytes, respectively, had no major effect on the candidacidal activity of splenic effectors activated by AmB.

\section{Effect of AmB Treatment Schedule}

Previous studies have shown that optimal immunostimulatory anti-Candida effects follow treat- 
Table 5. Candidacidal activity of adherent spleen cells after in vitro exposure to different doses of $\mathrm{AmB}$.

\begin{tabular}{|c|c|c|c|c|}
\hline \multirow{2}{*}{$\begin{array}{c}\text { In vitro incubation } \\
\text { with } \mathrm{AmB} \\
(\mu \mathrm{g} / \mathrm{ml})^{\mathrm{a}}\end{array}$} & \multicolumn{2}{|c|}{${ }^{51} \mathrm{Cr}$ Specific release $(\%)^{\mathrm{b}}$} & \multicolumn{2}{|c|}{ cfu inhibition $(\%)$} \\
\hline & $10: 1$ & $5: 1$ & $5: 1$ & $1: 1$ \\
\hline Untreated control & 14.3 & 10.4 & $40.2^{d}$ & 21.7 \\
\hline 0.1 & 15.3 & 11.8 & 41.8 & 24.9 \\
\hline 0.5 & 15.8 & 11.9 & 57.8 & 36.1 \\
\hline 1.0 & 17.3 & 11.4 & $63.6^{*}$ & $40.3^{*}$ \\
\hline 5.0 & 16.3 & 11.8 & $72.3^{*}$ & $46.4^{*}$ \\
\hline 10 & $28.5^{*}$ & $23.3^{*}$ & $96.1 *$ & $51.0^{*}$ \\
\hline 20 & $20.3^{*}$ & $16.4^{*}$ & $95.3 *$ & $43.0^{*}$ \\
\hline 10, freeze-thawed $^{c}$ & 1.2 & 0.8 & 3.1 & 1.2 \\
\hline
\end{tabular}

a Plastic adherent spleen cells from $\mathrm{CD} 2 \mathrm{~F} 1$ mice were cultured for 3 hours with different concentrations of $\mathrm{AmB}$.

b Ratios are effector to target cells. Data are the means of quadruplicate samples. Standard errors, usually $<1.5 \%$, have been omitted.

c Spleen cells treated in vitro with $\mathrm{AmB} 10 \mu \mathrm{g} / \mathrm{ml}$ were disrupted by repeated freeze-thawing prior to their use as effectors in the assay.

d The actual number of cfu was 150 in the absence of effectors.

* $P<0.01$ (AmB-treated versus untreated cells) according to the Student's " $t$ " test.

ment of mice with a single dose of $\mathrm{AmB} 10 \mathrm{mg} / \mathrm{kg}$ administered $2 \sim 8$ days before microbial challenge ${ }^{1)}$. In the present study, we investigated the impact of repeated drug administrations over a prolonged period of time. Table 4 shows the results. It is apparent that a single dose of $10 \mathrm{mg} / \mathrm{kg}$ administered 8 days before Candida challenge was as effective as 5 daily (days -12 to -8 ) exposures to AmB $2 \mathrm{mg} /$ $\mathrm{kg}$. The same fractionated dose, on the other hand, was largely ineffective when administered every other day from day -16 to -8 . Similar results were obtained with $\mathrm{AmB} 50 \mathrm{mg} / \mathrm{kg}$.

In Vitro Activation of Macrophages by $\mathrm{AmB}$

Studies were also conducted in order to establish the optimal conditions of in vitro exposure of macrophages which would induce candidacidal activity. Following preliminary indications ${ }^{1)}$, plastic adherent spleen cells from intact mice were incubated in vitro for 3 hours with a range of AmB concentrations $(0.1 \sim 20 \mu \mathrm{g} / \mathrm{ml})$. At the end of the incubation time, the cells were extensively washed and used as effectors in a ${ }^{51} \mathrm{Cr}$-release and a cfu inhibition assay. Table 5 shows the results. It is apparent that strong anti-Candida activity was achieved by exposure of macrophages to AmB $10 \mu \mathrm{g} / \mathrm{ml}$. Freezethawed AmB-treated spleen cells had no cytotoxic activity against Candida, thus ruling out any direct involvement of $\mathrm{AmB}$ which might have remained associated with the effector cells. In subsequent experiments, the effect of incubation with $\mathrm{AmB} 10 \mu \mathrm{g} / \mathrm{ml}$ for varying lengths of time was studied. Fig. 1 shows that, on exposure of macrophages to the drug for $15,30,60,120$ or 240 minutes or 24 hours, optimal anti-Candida effects were induced by a contact of at least 60 minutes. A series of experiments was also devoted to clarifying some kinetic aspects of the AmB-induced macrophage activation. Adherent spleen cells, either from intact or AmB-treated $(10 \mathrm{mg} / \mathrm{kg}$, day -8) mice were cultured in vitro for varying lengths of time before being tested in a ${ }^{51} \mathrm{Cr}$-release and cfu inhibition assays. Effector cells activated in vitro by $\mathrm{AmB}(10 \mu \mathrm{g} / \mathrm{ml}, 3$ hours) were also assayed according to the same schedule. Fig. 2 shows that all of the effectors tested gradually lost their cytotoxic potential if cultured in vitro in the absence of AmB over a 6-day period.

Kinetics of Phagocytosis by AmB-activated Macrophages

The phagocytic efficiency of macrophages activated by $\mathrm{AmB}$ was monitored at different times 
Fig. 1. Effect of the time of in vitro AmB incubation with normal adherent spleen cells on their candidacidal activity.

O, $\square$, Untreated control spleen cells; , spleen cells incubated with AmB.

Plastic adherent spleen cells from normal CD2F1 mice were incubated in vitro with medium or AmB $(10 \mu \mathrm{g} / \mathrm{ml})$ for various times. After that the effector cells were repeatedly washed and assayed against $C$. albicans target cells.

Data are the means of quadruplicate samples. Standard errors, usually $<1.5 \%$ for chromium release assay (CRA) and $<4.5 \%$ for cfu assay have been omitted. Ratio of effectors to target cells was 10: 1 for CRA and 2.5: 1 for cfu assay.

Arrows, $P<0.01$ (AmB-treated versus untreated cells) according to Student's " $\mathrm{t}$ " test.
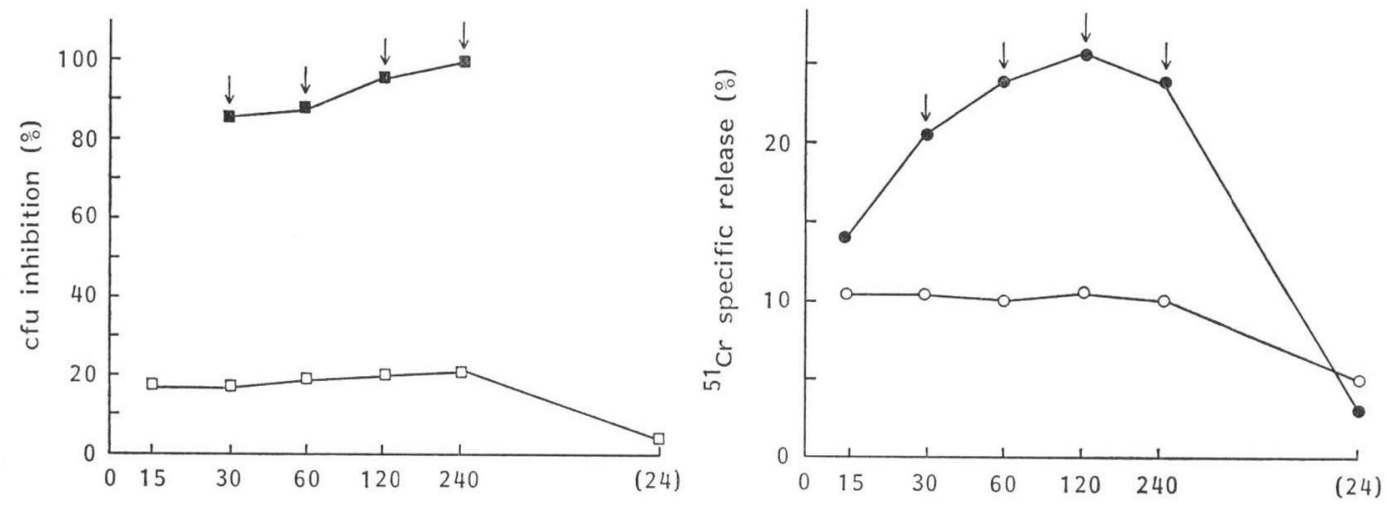

Time of in vitro incubation with AmB (minutes and (hours))

Fig. 2. Persistance in vitro of candidacidal activity of plastic adherent spleen cells from normal CD2F1 mice incubated in vitro with $\mathrm{AmB}$ or from $\mathrm{AmB}$-treated mice.

$\mathrm{O}, \square$, Spleen cells from untreated control mice; - , spleen cells from AmB-treated mice; 圆, spleen cells from untreated mice incubated in vitro with $\mathrm{AmB}$.

$\mathrm{AmB}(10 \mathrm{mg} / \mathrm{kg})$ was given ip as a single injection 8 days before collection of splenocytes for the in vitro assay. Plastic adherent spleen cells from normal mice were incubated for 2 hours with AmB $(10 \mu \mathrm{g} / \mathrm{ml})$.

Plastic adherent spleen cells from normal or AmB-treated mice or activated in vitro with AmB were cultured at different times before their use as effector cells against $C$, albicans.

CRA (A) and cfu (B) assays were performed at effector to target ratio of 10: 1 and 5: 1 respectively. Standard errors, usually $<1.5 \%$ for CRA and $<4.5 \%$ for cfu assay, have been omitted.

Arrows, $P<0.01$ (AmB-treated versus untreated cells) according to Student's "t" test.

$(A)$

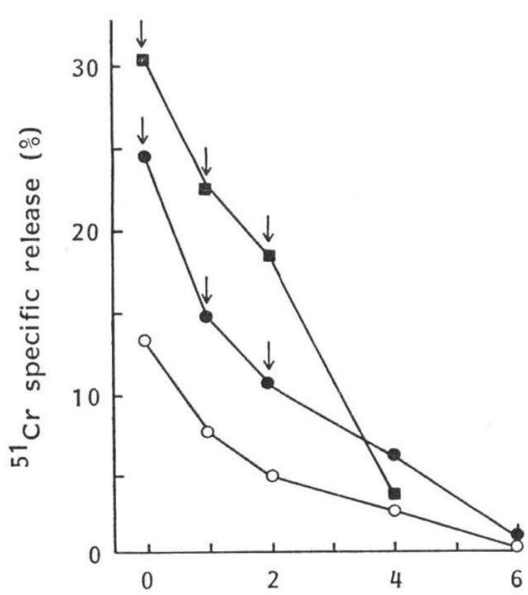

(B)

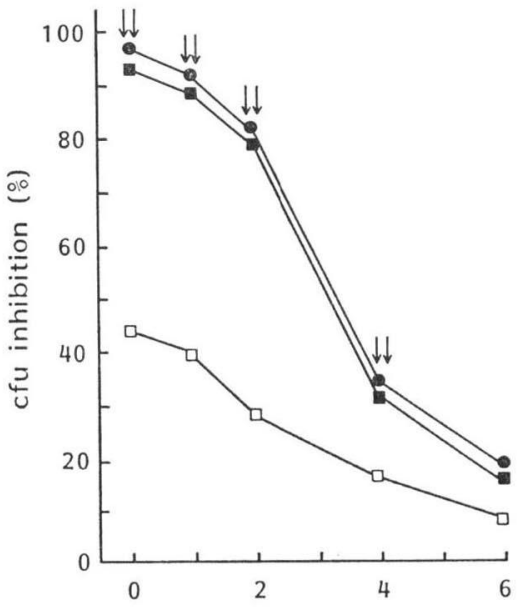

Time of effector cell culture before evaluation of candidacidal activity (days) 
Fig. 3. Effect of AmB administration on phagocytic efficiency in vitro of plastic adherent spleen cells against inactivated $C$. albicans microorganisms.

$\square$, Untreated control CD2F1 mice; 圆, AmB-treated mice.

The results were obtained on 200 adherent spleen cells.
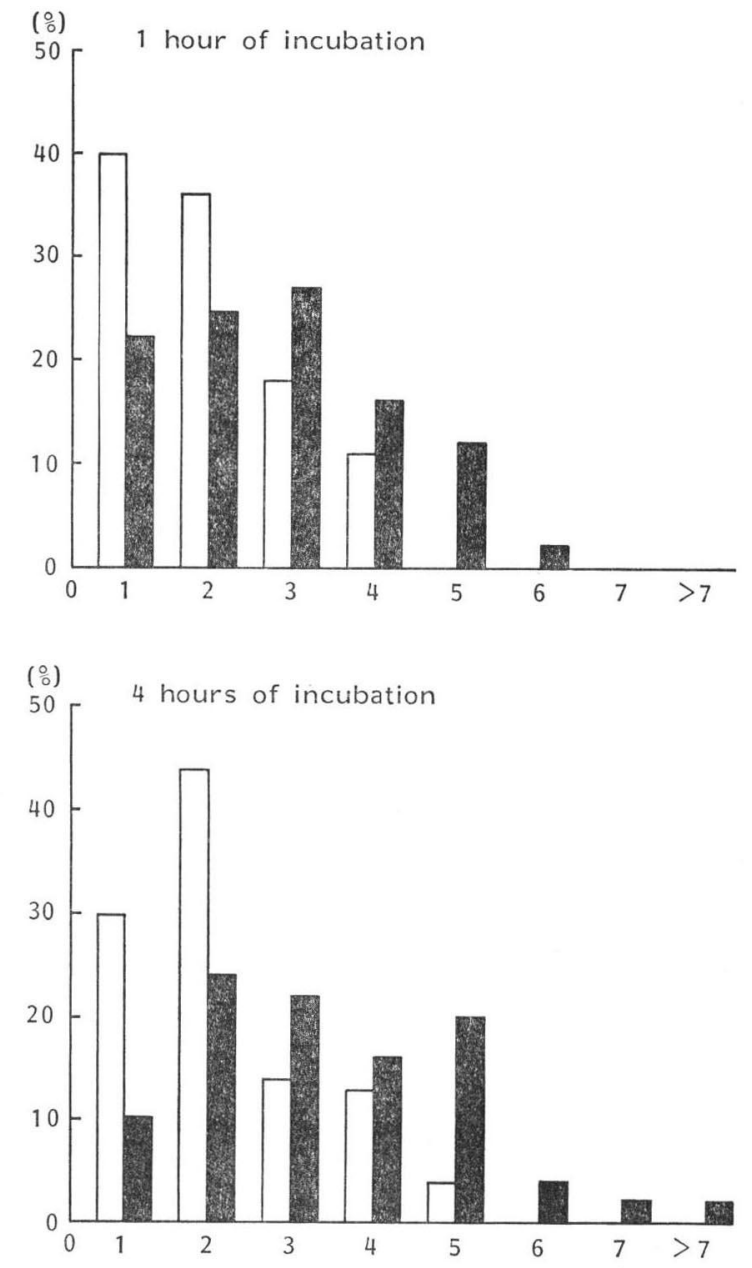

Number of $C$. albicans ingested for a single phagocytic cell

during the incubation of the effector cells with inactivated C. albicans microorganisms. Fig. 3 shows the results in terms of number of yeast particles ingested by a single phagocytic cell at 1 and 4 hours of incubation. It appears that the phagocytic activity of AmB-treated macrophages was considerably higher than that of controls. In another experiment, adherent spleen cells from intact or AmB-treated $(10 \mathrm{mg} / \mathrm{kg}$, day -8$)$ mice were incubated in vitro with inactivated C. albicans at the ratio of 1:5. Fig. 4 shows the results in terms of number of ingested yeast particles per 100 effectors as well as percentage of cells that had ingested at least one C. albicans particle. Again, the AmB-activated macrophages displayed an enhanced phagocytic ability.

\section{Discussion}

The present paper follows previous observations by our group that AmB can exert considerable 
anti-Candida activity through a mechanism largely independent of its chemotherapeutic properties ${ }^{1)}$. Indeed, this activity appeared in our preliminary investigations to be rather related to the immunoadjuvant effects that $\mathrm{AmB}$ has been shown to exert in experimental tumor ${ }^{12)}$ as well as infection models ${ }^{13,14)}$. The majority of these studies indicated activated macrophages as the principal mediators of the immunoadjuvant activity of $A m B^{15 \sim 17)}$. Our present study shows that cells with candidacidal properties can be recovered from mice treated with $\mathrm{AmB}$. These cells appear to be macrophages by both morphological and functional criteria. They are activated in vivo by $\mathrm{AmB}$ in a dose-dependent fashion under selected treatment conditions. A single dose of $10 \mathrm{mg} / \mathrm{kg}$ has effects comparable to those of 5 daily exposures to $2 \mathrm{mg} / \mathrm{kg}$. The activity is lost when the repeated dosages are given on an alternate day basis. No additional benefits, on the other hand, are obtained if the cumulative dose is raised to $50 \mathrm{mg} / \mathrm{kg}$. Thus, macrophage activation by $\mathrm{AmB}$ seemed to develop over a prolonged period of time following administration of the drug in adequate amounts. In vitro studies of macrophage activation by $\mathrm{AmB}$ were performed in which we tested different AmB concentrations and different exposure times. Again there appeared to be a threshold value $(10 \mu \mathrm{g} / \mathrm{ml})$ below which no significant activation could be obtained. Macrophage activation, which was evident in both the chromium release assay (CRA) and cfu inhibition tests, gradually declined when the cells, activated either in vivo or in vitro, were kept under in vitro conditions for varying lengths of time before testing. Studies were also
Fig. 4. Effect of $A m B$ administration on in vitro phagocytic capability of plastic adherent spleen cells incubated with inactivated C. albicans microorganisms.

$\mathrm{AmB}(10 \mathrm{mg} / \mathrm{kg})$ was given ip as a single injection 8 days before collection of splenocytes for the in vitro assay.

Adherent spleen cells from normal $(O)$ or AmBtreated ( mice were incubated in vitro with inactivated $C$. albicans at a ratio of $1: 5$.

The results are obtained counting 100 adherent spleen cells for each incubation period.

In parentheses are reported the numbers of phagocyted cells for 100 adherent cells at $5^{\prime}, 1$ or 4 hours of in vitro incubation.

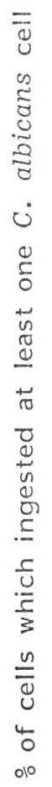

devoted to clarifying the mechanisms by which the activated macrophages exert the increased antiCandida activity. It was found that the phagocytic efficiency of AmB-activated macrophages was considerably enhanced with respect to untreated controls both in terms of kinetic parameters of phagocytosis as well as total numbers of Candida particles ingested. Moreover, on incubation of AmBactivated macrophages with live Candida, marked inhibition of hyphae formation was observed (data not shown).

In conclusion, the data of the present paper suggests the concept that in vitro or in vivo exposure of macrophages to $\mathrm{AmB}$ results in increased candidacidal activity. This observation might be useful toward a more thorough understanding of the mechanisms underlying the therapeutic efficacy of AmB as an antifungal agent.

\section{Acknowledgments}

This work was supported by Contract no. 83.00628 .52 and Contract no. 83.02916 .52 within the Progetto Finalizzato per il Controllo delle Malattie da Infezione from the Consiglio Nazionale delle Ricerche, Italy. We are grateful to EILEEN ZANNETTI for her excellent assistance in the preparation of this manuscript. 


\section{References}

1) Bistoni, F.; A. Vecchiarelli, R. Mazzolla, P. Puccetti, P. Marconi \& E. Garaci: Immunoadjuvant activity of amphotericin $\mathrm{B}$ as displayed in mice infected with Candida albicans. Antimicrob. Agents Chemother. 27: 625 631, 1985

2) Blanke, T. J.; J. R. Little, S. F. Shirley \& R. G. LynCh: Augmentation of murine immune responses by amphotericin B. Cell Immunol. 33: 180 190, 1977

3) ShIRley, S. F. \& J. R. LitTle: Immunopotentiating effects of amphotericin B. I. Enhanced contact sensitivity in mice. J. Immunol. 123: 2878 2882, 1979

4) Baccarini, M.; F. Bistoni, P. Puccetti \& E. Garaci: Natural cell-mediated cytotoxicity against Candida albicans induced by cyclophosphamide: Nature of the in vitro cytotoxic effector. Infect. Immun. 42: $1 \sim 9,1983$

5) Baccarini, M.; E. Blasi, P. Puccetti \& F. Bistoni: Phagocytic killing of Candida albicans by different murine effector cells. Sabouraudia 21: $271 \sim 286,1983$

6) Marconi, P.; F. Bistoni, L. Boncio, A. Bersiani, P. Bravi \& M. Pitzurra: Utilizzazione di una soluzione salina ipertonica di cloruro di potassio $(3 \mathrm{M} \mathrm{KCl})$ per l'estrazione di antigeni solubili da Candida albicans. Ann. Scalvo 18: 61 66, 1976

7) Van Uden, N. \& H. Buckely: The yeasts: a taxonomic study. In Candida Berkhout. Ed., J. Lodder pp. 914 921, North Holland Publishing Co., Amsterdam, 1970

8) Julius, M. H.; E. Simpson \& L. A Herzenberg: A rapid method for the isolation of functional thymusderived murine lymphocytes. Eur. J. Immunol. 3: 645 652, 1973

9) Landolfo, S.; R. B. Herberman \& H. T. Holden: Macrophage-lymphocyte interaction in migration inhibition factor (MIF) production against soluble or cellular tumor associated antigens. I. Characteristics and genetic control of two different mechanisms of stimulating MIF production. J. Immunol. 121: 695 701,1978

10) Kasai, M.; M. Ifamori, Y. Nagai, K. Okamura \& T. Tada: A glycolipid on the surface of mouse natural killer cells. Eur. J. Immunol. 10: 175 181, 1980

11) Bistoni, F.; M. Baccarini, E. Blasi, P. Puccetti \& P. Marconi: A radiolabel release microassay for phagocytic killing of Candida albicans. J. Immunol. Methods 52: 369 377, 1982

12) Little, J. R.; T. J. Blanke, F. Valeriote \& G. Medoff: Immunoadjuvant and antitumor properties of amphotericin B. In Immune Modulation and Control of Neoplasia by Adjuvant Therapy. Ed., M. A. Chirigos, pp. $381 \sim 394$, Raven Press, New York, 1978

13) Thomas, M. Z.; G. Medoff \& G. S. Kobayashi: Changes in murine resistance to Lysteria monocytogenes infection induced by amphotericin B. J. Infect. Dis. 127: $371 \sim 377,1973$

14) Olds, G. R.; S. J. Stewart \& J. J. Ellner: Amphotericin B-induced resistance to Schistosoma mansoni. J. Immunol. 126: 1667 1670, 1981

15) LiN, H.-S.; G. Medoff \& G. S. Kobayashi: Effects of amphotericin B on macrophages and their precursor cells. Antimicrob. Agents Chemother. 11: 154 160, 1977

16) Chapman, H. A., Jr. \& J. B. HrbBs: Modulation of macrophage tumoricidal capability by polyene antibiotics: Support for membrane lipid as a regulatory determinant of macrophage function. Proc. Natl. Acad. Sci. U.S.A. 75: 4349 4353, 1978

17) Mehta, R. T.; K. Mehta, G. Lopez-Berestein \& R. L. Juliano: Effect of liposomal amphotericin B on murine macrophages and lymphocytes. Infect. Immun. 47: 429 433, 1985 